\title{
Progressivity of Judges in Domestic Violence Disputes Settlement in the Case of Divorce in the Religious Court
}

\author{
Nita Triana* \\ Institut Agama Islam Negeri (IAIN) Purwokerto \\ Email: triananita@ymail.com
}

\begin{abstract}
This study aims to describe and analyze the Judge Progressiveness in the case of a divorce related to domestic violence. The principle of law governing civil judges is passive, in reality this principle creates difficulties for women (wives) victims of domestic violence to achieve justice. The research method used is non-doctrinal tradition with a sociolegal approach, and qualitative descriptive analysis. The results of the study illustrate. Religious Courts Judges as one of the law enforcers are very potential to seek justice for victims of domestic violence, the majority of whom are women, because many cases of domestic violence ended in divorce cases in the Religious Courts. But the consideration of the religious Court Judge in deciding the case of a divorce petition is not yet progressive, the Judge still adheres to the principle of law, that the Civil Judge is passive. So that when the Plaintiff (Wife) does not demand income and compensation from her husband. The Plaintiff (Wife) as a victim of domestic violence will not get a living idah, mut'ah, maskan, kiswah and any compensation from the Defendant (Husband). Religious Court Judges have not yet explored other relevant legislation, including progressive religious texts that favor women as victims of domestic violence to strengthen the building of their arguments. Whereas in the case of divorce by talak, the Judge views the law in book in his legal considerations by giving protection to the wife, namely by giving the wife the right to earn a living Idah, Mutah (a living for one year to entertain the wife divorced by
\end{abstract}

* Dosen tetap Jurusan Syari'ah Institut Agama Islam Negeri (IAIN) Purwokerto. 
her husband), maskan and kiswah, according with what is stipulated in the Marriage Law and the Compilation of Islamic Law. The paradigm of the operation of the Judge in a country with a pluralistic culture such as Indonesia, it's time to change to a more progressive direction, Judge is no longer limited to the existence of a mouth that sounds the sentence of the law (le judge est uniquenment la bouche qui pronance le most de lois) Judge also not tools designed to be logical and work mechanically, but whole people who have sensitivity to humanitarian and social concerns. Progressive judges learn and are good at making interpretations that are not literal (connotative), and have a high sense of empathy to be able to catch social norms that contextually support each prescription of the Act. The holistic understanding of the judges has the potential to provide justice for women victims of domestic violence.

Keywords: Progressive Judge, Divorce, Domestic Violence, Religious Court.

\section{Abstrak}

Penelitian ini bertujuan untuk mendeskripsikan dan menganalisis tentang Progresifitas Hakim dalam perkara cerai gugat dan cerai talak yang berkaitan dengan KDRT (Kekerasan dalam Rumah Tangga). Azas hukum yang mengatur tentang Hakim perdata bersifat pasif, dalam realitasnya menimbulkan kesulitan perempuan (Isteri) korban KDRT untuk mencapai keadilan. Metode penelitian yang digunakan adalah, penelitian dengan tradisi non doktrinal dengan pendekatan socio- legal, dan analisis deskriptif kualitatif. Hasil penelitian menggambarkan. Hakim Pengadilan Agama sebagai salah satu penegak hukum sangat potensial untuk mengupayakan keadilan bagi korban KDRT yang mayoritas adalah perempuan, karena banyak kasus KDRT yang berakhir dalam kasus gugat cerai di Pengadilan Agama. Tapi pertimbangan Hakim Pengadilan agama dalam memutus perkara cerai gugat belum progresif, Hakim masih berpegang kepada azas hukum, bahwa Hakim perdata bersifat pasif. Sehingga ketika Penggugat (Isteri) tidak menuntut nafkah dan kompensasi dari Suaminya. Penggugat (Isteri) sebagai korban KDRT tidak akan mendapat nafkah idah, mut'ah, maskan, kiswah dan kompensasi apapun dari Tergugat (Suami). Hakim Pengadilan Agama belum banyak menggali perundang-undangan lain yang relevan, termasuk teks-teks keagamaan progresif yang berpihak pada perempuan sebagai korban KDRT untuk memperkuat bangunan argumentasinya. Sedangkan dalam perkara cerai talak, Hakim berpandangan law in book dalam pertimbangan hukumnya dengan memberi perlindungan kepada Isteri,

Ulul Albab: Jurnal Studi dan Penelitian Hukum Islam 
yaitu dengan memberikan hak pada Isteri untuk mendapatkan nafkah Idah, Mutah (nafkah selama satu tahun untuk menghibur Isteri yang di cerai Suaminya), maskan dan kiswah, sesuai dengan yang diatur dalam Undang-Undang Perkawinan dan Kompilasi Hukum Islam. Paradigma bekerjanya Hakim di negara yang berkultur majemuk seperti Indonesia, sudah waktunya berubah ke arah yang lebih progresif, Hakim bukan lagi sebatas bereksistensi sebagai mulut yang membunyikan kalimat undangundang (le judge est uniquenment la bouche qui pronance le most de lois) Hakim juga bukan piranti yang dirancang untuk berlogika dan bekerja secara mekanik, melainkan manusia seutuhnya yang punya kepekaan pada ikhwal kemanusiaan dan kepedulian sosial. Hakim progresif belajar dan pandai membuat interpretasi yang tidak harfiah (konotatif), dan memiliki rasa empati yang tinggi agar mampu menagkap norma-norma sosial yang secara kontekstual melatari setiap preskripsi Undang Undang. Pemahaman holistik yang dimiliki para hakim, sangat berpotensi memberikan keadilan bagi perempuan korban KDRT.

Kata kunci: Hakim Progresif, Cerai gugat, Cerai talak, KDRT, Pengadilan Agama

\section{Introduction}

eciding or making a decision in law is carried out by
many actors, not only by the Judge, even though it must
be admitted, that the Judge's work in making a decision is a deciding job that par parity. Deciding work is also faced by prosecutors, advocates, bureaucrats and academics, in accordance with the characteristics of each job.

Decision-making is faced with picky work and therefore the level of subjectivity and sociology needs to be recognized and taken into account. A study of the same theme or topic may be different, the results are due to optical choices, methodology and ideology. The study of the work decided by the Judge, not only focused on the work of "examining and adjudicating according to law", but rather broader than that.

The main task of the Judge as mentioned earlier is to examine, hear and decide a case. Judges cannot refuse cases with legal reasons that are not clear or not yet available. Therefore it can be said that for the Judge to decide that every case submitted 
4 Nita Triana

to him is an obligation. In addition the Judge is also tasked to link abstract rules in the law with concrete facts from the case he examined.

There are several streams that influence the Judge, the flow of legis, which tends to view the judge as nothing more than a trumpet law (bouche de la loi). Then came the flow of legal discoveries by the Judge, who viewed the Judge as being able to fill the statutory vacuum by means of legal construction or interpretation. Finally, there emerged a realist school in the United States and Scandinavia, which in essence saw the Judge not merely "find the law" but "shape the law" through his decision.

According to satjipto rahardjo (2009) ${ }^{1}$, progressive law was born from the influence of non-positivism, where this sect saw that the Judge was not only a trumpet of the Law but the Judge could find the law and form the law. This flow changes quickly and makes a reversal based on theory and also practical law.

The mindset that is positivistic and non-positivistic at the praxis level gives rise to a different tendency of Judges to carry out the meaning or interpretation of the law relating to examining, adjudicating and deciding cases. Likewise, Religious Court Judges cannot be separated from the development of the Judge's thinking paradigm. In the case of divorce or divorce, the task of the Religious Court Judge is not only to divorce the spouse, but to examine, try and decide to achieve justice for the parties.

Interesting to analyze is how the mindset or paradigm of the Religious Court Judge in examining, adjudicating and deciding divorce petition cases and divorce by talak in cases of

1 Satjipto Rahardjo, Membedah Hukum Progresif, (Jakarta: PT Kompas, 2006), 25-30; See also, Satjipto Rahardjo, "Sekitar Hakim yang Memutus", Kumpulan Tulisan Program Doktor Ilmu Hukum, (Semarang: UNDIP, 2009), 5-12.

Ulul Albab: Jurnal Studi dan Penelitian Hukum Islam 
domestic violence. Women's National Commission (Komnas Perempuan) notes that the number of domestic violence cases handled through the Religious Courts is very significant, namely in 2016, cases handled by 359 Religious Courts reaching 245,548 cases, which means $94.75 \%$ of the total cases of violence against women numbered 259,150. In other words, the majority of domestic violence in domestic violence is resolved and ends with divorce in the Religious Court, meaning that women victims of domestic violence always rely on the Religious Court - and its judges - to escape the bondage of violence ${ }^{2}$.

Most domestic violence cases handled by the Religious Courts are 'hidden' in the case of a divorce case. The phenomenon above is not much different from the findings of Sulistyawati Irianto $(2008)^{3}$ when conducting research on decisions of the Supreme Court from 1955 to 2003 concerning cases of violence against women. Sulistyawati in her research shows that cases of violence against women actually "hide" in civil cases namely divorce, marriage and inheritance.

This finding has actually undermined the boundaries of criminal and civil matters in the context of domestic violence. Because for women victims of violence, they do not care whether the problems they face include criminal or civil matters, what they want is how to get out of the problems they face, thus ignoring the criminal issues that accompany them and preferring to pursue a civil route.

Some of the findings above show that sociologically the Religious Courts can no longer ignore the issue of women

\footnotetext{
${ }^{2}$ https://www.komnasperempuan.go.id/reads-catatan-tahunankekerasan-terhadap-perempuan-2017

${ }^{3}$ Sulistyowati Irianto dan Antonius Cahyadi, Runtuhnya Sekat Perdata dan Pidana: Studi Peradilan Kasus Kekerasan terhadap Perempuan, (Jakarta: Yayasan Obor Indonesia, 2008), 20-25.
} 
6 Nita Triana

victims of domestic violence who submit their problems through the Religious Courts, because usually victims of domestic violence in religious courts prefer not to continue the case to the Police or to the District Court. If anyone has reported to the police, many of them later revoke it. According to him, this is caused by several factors including; trauma victims deal with perpetrators; victims are afraid to meet again with the perpetrators because they have been tried in a Religious Court; victims are reluctant to deal with the court because it takes time and costs; and victims want to immediately forget the dark past and re-organize the future, especially if there are children.

Religious Court Judges are law enforcers who are closely related to the enforcement of various laws relating to the rights and obligations of a husband and wife in marriage. The main thing that is also the obligation of the Religious Court Judge is its legal mandate as the party charged with deciding cases. Religious Court Judges cannot merely refer rigidly to legislation such as the Marriage Law which has limitations in capturing every complex spectrum of domestic violence events, but also is required to create, review and skillfully build holistic arguments (comprehensive and broad) from various national legislation available ${ }^{4}$.

Based on the background of the problem and the results of previous studies, it is considered very important to analyze comprehensively about the Progressivity of Religious Court Judges in the Case of Divorce petition and Divorce by talak in the Case of Domestic Violence in the Purbalingga Religious Court. This research is part of the research Recontruction of Legal Reasoning of Religious Courts Judges in Domestic Violence Cases

4 Nita Triana, "Progresifitas Hakim dalam Dinamika Positivisasi Hukum Islam di Indonesia", dalam Al manahij: Jurnal Kajian Hukum Islam, Vol.5, No.2, (Purwokerto: STAIN Purwokerto, 2011), 257.

Ulul Albab: Jurnal Studi dan Penelitian Hukum Islam 


\section{Research Methods}

This research belongs to the tradition of non-doctrinal legal research with a sociolegal approach ${ }^{5}$. The research subject was the Judge, who was supported by informants and resource persons. Data was collected by using in-depth interviews, document observation and study. Data were analyzed following an interactive model consisting of data collection activities, and drawing conclusions / verification. To guarantee the validity, objectivity and reliability of the data, triangulation is examined. In this study, triangulation of sources and methods was used. Triangulation of sources and methods is done by cross-checking between data sources and one method with other data, both obtained through interviews, observation, documentation / library studies and field notes ${ }^{6}$.

\section{Progressive Law and Progressive Judge}

Progressive Law theory by Satjipto Rahardjo confirms that the law is for man, and not the other way around. "The law is not just building regulations, but also building ideas, culture, and goals", further said that the law needs to be re-thought in the philosophical essences, that is the law of man. With this philosophy, then the human becomes the determinant and the point of legal orientation. The law is in charge of serving people, not the other way around. Therefore, the law is not an institution independent of human interests. The quality of the law is

5 Sulistyowati Irianto dan Lim Sing Meij, "Praktek Penegakan Hukum: Arena Penelitian Sosiolegal yang Kaya" dalam Metode Penelitian Hukum: Konstelasi dan Refleksi, (Jakarta: Yayasan Obor, 2009), 174-177. See also, Mark Van Hoecke, Methodologies Of Legal Research: Which Kind of Method For What Kind of Dicipline?, Europian Academy of Legal Theory, Vol:9, (UK, Oxford: Hart Publishing, 2011), 40-42.

${ }^{6}$ Strauss and J Corbin, Busir, Qualitative Research, Grounded Theory Procedure and Techniques, (London: Sage Publication, 1990). 
8 Nita Triana

determined by its ability to serve human wellbeing. It causes progressive laws embrace the ideology: the Pro-Justice Law and Pro-People Law. According to this theory, justice cannot be directly identified through a process of formal logic. Justice is acquired through institutions, therefore, formal logical arguments "sought" after justice are found to frame the juridicalformal decisions that are believed to be just. Therefore the concept of progressive law, law does not serve for itself, but for purposes that are outside of that self ${ }^{7}$.

In the concept of progressive law, law does not exist for its own sake, but for a purpose that is outside of itself. Therefore, progressive law leaves the tradition of analiytical jurisprudence or rechtsdogmatiek. Tradition or flow only looks into the law and busied itself by discussing and carrying out inward analysis, especially law as a building of regulations which are considered systematic and logical. In rechtsdogmatiek the world is outside the law such as humans, society, welfare, change is ignored.

Unlike rechtsdogmatiek, progressive law wants to consciously place its presence in close relations with humans and society, borrowing the term Nonet \& Selznick ${ }^{8}$, progressive law has a responsive type. In the responsive type, the law will always be linked to the purpose of the goal outside the textual narrative of the law itself. Progressive law is also close to the flow of legal realism, which teaches that the law is not seen from the perspective of the law itself, but is seen and judged by the social objectives to be achieved and the consequences arising from the

${ }^{7}$ Rodiyah, “Philosophy of Progressive Law On Establishment of Laws and Regulation in The Context of Substantive justice: An Indonesian Experience", International Journal of Business, Economics and Law, Vol. 13, Issue 4 (August), 2017, 125.

8 Philippe Nonet and Philip Selznick, Torward Responsive Law: Law and society in transition, (New Brunswick (U.S.A.) \& London (U.K.): Transaction Publisher, 2011), 110.

Ulul Albab: Jurnal Studi dan Penelitian Hukum Islam 
operation of the law. In the flow of realism, people's understanding of the law goes beyond regulations or document texts and always directs their faces to completeness, adequacy, facts, actions and powers9.

Progressive law has a big goal in the form of human welfare and happiness, so the law is always in the status of 'law in the making'. The law does not exist for itself and is not final ${ }^{10}$. Every stage of the legal journey is the decisions made to achieve the ideal of the law, both made by the legislative, executive and judicial branches (based on the judge's decision in the Court) each decision is terminal towards the next decision that is better. With this explanation, progressive law is always sensitive to changes that occur in society, both locally, nationally and globally. Faced with these changes, progressive law is called to appear to protect the people towards the ideal of law.

The judge in deciding the case other than based on the process specified in the procedural law, must also be based on argumentation or reason. While the meaning of "argument" is a reason that can be used to strengthen or reject an opinion, while argumentation is to provide reasons to strengthen or reject an opinion. The judge in deciding a case must present an argument, both related to the subject matter and the branch of the case.

Progressive judges are judges who have empathy, this is very likely to arise if the judges understand the root of the problem which often cannot be seen from the conditions that occurred at that time. Searching for a series of events behind

9 Carol L. Chomsky, "Progressive Judges in a Progressive Age: Regulatory Legislation in the Minnesota Supreme Court, 1880-1925“, Law and History Review, Vol. 11, No.2, (Autumn, 1993), (USA: American Society for Legal History US, 2001), 383-440.

10 Syamsudin. M, "Rekonstruksi Pola Pikir Hakim Dalam Memutus Perkara Korupsi Berbasis Hukum Progresif", Jurnal Dinamika Hukum, Vol. 11, No. 1, (Purwokerto: UNSOED, 2011), 14-17. 
10| Nita Triana

someone to come to court requires mastery and holistic analytical skills.

Progressive law emphasizes the same weight for legal progress, legal actors and the system in which they are located, all elements are interrelated and support each other, what is the meaning of a progressive law, if there is no courage from law enforcement actors such as police, prosecutors, judge, and vice versa as brave as any law enforcers if the legal system does not support those who are progressive will instead become wrong parties (culprit) ${ }^{11}$.

Relating to the progressive Judge of the Religious Court Judge. The Religious Court is one of the executors of the judicial authority for Muslim justice seekers regarding certain civil matters as stipulated in the law. The position of the religious court limits its absolute competence as a court that is only authorized to handle certain civil cases. Therefore in Article 2 of Law No. 3 of 2006 concerning amendments to Law No. 7 of 1989 concerning the Religious Courts emphasized that: Religious Courts are one of the perpetrators of judicial power for Muslim justice seekers regarding certain cases as referred to in this Law.

With the affirmation of the authority of the religious court to administer law and justice regarding certain cases, it is intended to provide a legal basis for resolving cases of violations of the Laws that are under the authority of the Religious Courts, such as violations of marital law and so forth ${ }^{12}$.

${ }^{11}$ Satjipto Rahardjo, Hukum Progresif Sebuah Sintesa Hukum Indonesia, (Yogyakarta: Genta Publishing, 2009), 61. See, Satjipto Rahardjo, “Ilmu Hukum dan Fisiologi Otak", Kumpulan Tulisan Program Doktor Ilmu Hukum, (Semarang: UNDIP, 2009), 10-17. See also, Satjipto Rahardjo, Biarkan Hukum MengalirCatatan Kritis Tentang Pergulatan Manusia dan Hukum, (Jakarta: Penerbit Buku Kompas, 2008), 75-80.

${ }^{12}$ Abdul Manan dan Fauzan, Pokok-Pokok Hukum Perdata Wewenang Peradilan Agama, (Jakarta: Rajawali Pers 2000), 77.

Ulul Albab: Jurnal Studi dan Penelitian Hukum Islam 
Most domestic violence cases handled by the Religious Courts are 'hidden' in the case of a divorce case. Continuing quarrels are usually followed by physical violence. One of the reasons that wives ask for divorce in general is economic abandonment by their husbands - an act that according to the Law on the Elimination of Domestic Violence is one form of domestic violence.

Law No. 23 of 2004 concerning the Elimination of Domestic Violence (PKDRT) which conceptually has put a more progressive definition of family and domestic violence has been positively appreciated by law enforcement officials, including Religious Court judges. Procedurally, the religious justice institution is not a legal institution that accepts the mandate to enforce this law. However, because domestic violence cases are closely related to families and become one of the triggers of divorce - a case that is a religious court competence - the Religious Court is also a part of legal institutions that have a strategic role in the elimination of all types of domestic violence. the first door to reveal a variety of domestic violence that was previously neatly closed. Therefore, although it does not directly prosecute criminal acts, the religious court has a strategic role in uncovering the incidence of domestic violence.

Examination of divorce cases in the Religious Courts which have the nuances of domestic violence are very dilemma. This is because the Religious Courts do not have the authority to examine the criminal elements in the PKDRT Law, while one of the reasons for the divorce being filed is the existence of domestic violence, so that the Religious Courts cannot automatically prosecute those perpetrators of domestic violence.

Religious Courts, as an instrument for seeking justice, is expected to resolve family disputes that can prevent further divisions within the family. The implementation of religious courts is also different from the general court because religious judges also have the duty to reconcile and seek ways to resolve 
$12 \mid$ Nita Triana

outside the court in the form of mediation as mandated in Supreme Court Regulation (PERMA) Number 1 of 2008 concerning Mediation, before deciding cases in the litigation process. Therefore a more empathetic and family atmosphere is an important factor to consider in completing cases in the Religious Courts.

Understanding the psycho-social context of victims who are wrapped up in the cycle of violence, the cycle of isolation and confined to the power of the perpetrator, is very useful for judges in exercising their authority to resolve this family case. In general, women victims of domestic violence come to the Religious Courts to settle domestic abuses are the final choice after taking various methods of settlement. This is evident in almost all cases in the Religious Courts which always mention the implementation of the two parties' mediation efforts, but fail $^{13}$.

The Judges have the authority to seek settlement of kinship before deciding to break the marital relationship. With such a situation, when interpreting the problems in the Religious Courts it is important to be able to examine the issue more deeply and empathize with the victims. Judges in the Judge's Code of Conduct established by the Chair of the Indonesian Supreme Court are required to be fair. This means that the judge must place the parties equally before the law ${ }^{14}$. However, judges are also required to be wise and wise in the sense that judges must pay attention to gender fair norms that live in society both legal norms, religion, morality, and pay attention to the situation and

13 See, Aisyah S., Parker L, “Problematic conjugations: Women's agency, marriage, and domestic violence in Indonesia". Asian Studies Review Journal ,Vol. 38, 2014, 205-223.

14 Anonim. Pedoman Perilaku Hakim (Code of Conduct) Mahkamah Agung Republik Indonesia.

Ulul Albab: Jurnal Studi dan Penelitian Hukum Islam 
\begin{tabular}{l|l} 
Progressivity of Judges in .... & 13
\end{tabular}

conditions that exist and are able to take into account the consequences of their decisions ${ }^{15}$.

\section{Progressivity of Judges in the Case of Talak Divorce and Claims Divorce Related to KDRT (Domestic Violence)}

Divorce rates in Purbalingga Regency during 2015 to July 2016 are still high. Divorce is dominated by the wife's claim for divorce submitted to the husband. The majority of divorces are carried out by a husband and wife who are farmers and laborers. And female workers (TKW). The Purbalingga Religious Court noted, in 2015 the cases that entered and were decided reached 2,621 cases. The number of cases terminated increase 272 decisions, compared to 2014 as many as 2,349 cases. Whereas in 2016 when this study was conducted, January to July cases received were 1,495 . Of the number of cases received and those decided, the majority are divorce cases.

Divorce cases, especially divorce petition from women, still dominate. In 2015 as many as 1,667 cases of divorce petition, the amount was far more than the case of divorce by talak ( husband to wife ), namely as many as 610 cases. Data for 2016 (when this study took place) the data had not been fully recapitulated. Data from January to July showed data on marriage cases reaching 1,295 cases dominated by divorce, both divorce petition and divorce by talak as many as 1,251 cases. And isbath marriage is 158 cases. Data from divorce cases recorded 955 cases of divorce petition, and there were 296 cases of divorce by talak.

Divorce cases did dominate both 2015 and 2016. For the background factors when viewed from the case report which was decided in 2015 the most common cause of divorce was

15 Faqihuddin Abdul Kodir dan Ummu Azizah Mukarnawati, Referensi bagi Hakim Peradilan Agama tentang Kekerasan dalam Rumah Tangga, (Jakarta: Komnas Perempuan, Cet. I, 2013), 165. See also, Brian Z Tamanaha Z.. On the Rule of Law, (New York: Cambridge University Press, 2004), 11.

Vol. 2, No. 1, Oktober 2018, 1-29 
$14 \mid$ Nita Triana

because the factor of leaving the obligation or not giving birth both physically and mentally reached 990 cases. Economic conditions were 490 cases, and other factors were disputes between husband and wife which resulted in no harmony reaching 333 cases. "There were 82 cases of third party disturbance ${ }^{16}$.

Based on the data above, it can be described that in the Purbalingga Religious Court in January-July 2016, all the cases received were 1,495 cases, and most of those cases were divorce matters, namely 1,251 cases. Furthermore, of the 1,251 divorce cases, the most dominating is the divorce petition, which is 955 . Divorce petition is a divorce filing by the wife of the husband. With regard to domestic violence, in divorce petition cases, cases of domestic violence are often hidden This can be seen from the further data, namely, the factors that cause divorce are dominated by the absence of the husband's responsibility for the family, economic problems (economic neglect), and the absence of harmony (continuous quarrels).

The higher rate of divorce petition than divorce talak indicates the strength of the wife's initiative in stopping domestic violence. most of the violence that occurs in victims of domestic violence is psychological violence. The problem is, as LBH APIK (2011) ${ }^{17}$ revealed, the proof of psychic violence is not easy. The only way to prove is a letter from a psychologist.

Psychological violence is actually quite bright in the reason for filing for divorce for reasons of lack of responsibility, economic neglect and constant fights, greatly opening up the

${ }^{16}$ the data was taken on 21 February 2017 at the Purbalingga Religious Court. and an interview with the Purbalingga Religious Court Clerk, Mr. Rosiful.

${ }^{17}$ LBH APIK Jakarta, Refleksi dan Catatan kerja LBH APIK Jakarta tahun 2011, (Jakarta: LBH APIK, 2012), 74; See also, Tali Tulab, “Tinjauan Status Wali Dalam Perkawinan Berdasar Pendekatan Feminis", Ulul Albab: Jurnal Studi dan Penelitian Hukum Islam, Vol. 1, No. 1, (Semarang: UNISSULA, 2017), 162.

Ulul Albab: Jurnal Studi dan Penelitian Hukum Islam 
opportunity for psychiatric domestic violence for the wife. As explained in Chapter 1. General Provisions Article 1 of The Elimination of Domestic Violence Law (PKDRT), In this Law what is meant by: 1 . Domestic violence is any act against a person, especially women, which results in the emergence of misery or suffering physically, sexually, psychologically, and / or neglected house holds including threats to commit acts, coercion, or seizure of freedom against the law in a household scope.

The next reason which shows how difficult it is to seek justice for women/wives of victims of domestic violence is stated by the Purbalingga Religious Court as follows: That it is very rare to find domestic violence as an excuse for divorce, because the party who filed the complaint was difficult in its verification in the Religious Court. Likewise from the Judge, it is rarely used Law Number 23 of 2004 concerning the Elimination of Domestic Violence (PKDRT) as a material for consideration of civil sanctions, although in the trial it was often revealed that physical and psychological violence was committed by the Defendant against the Plaintiff. Although there are a number of cases that the PKDRT Law has been made the Judge's legal considerations in divorce cases, but sanctions for defendants are still difficult to implement

As an example of a Divorce Petition, Number 1137 / Pdt.G / 2016 / PA.Pbg which has been decided in the Purbalingga Religious Court as follows: The fact in the Court shows that the Defendant (Husband), has left his wife and family, did not provide a living physically, and has abandoned his wife and family economically. has been included in the formulation of household neglect, From the case, that in fact there has been domestic violence when referring to Law No.23 of 2004 concerning Elimination of Domestic Violence as stipulated in Chapter 1. General Provisions Article 1 In this Law what is meant with: 1. Domestic violence is any action against a person, especially women, which results in the emergence of misery or 
16| Nita Triana

suffering physically, sexually, psychologically, and / or neglected households including threats to commit acts, coercion, or deprivation of liberty against the law in Household appliances.

In legal considerations, the Religious Court Judge, the case of the divorce petition above actually has used the Law on PKDRT (The Elimination of Domestic Violence), but this consideration does not have an impact on civil sanctions for the Defendant (Actor of Domestic Violence). The judge remains legistic and positivistic, holds the principle of law, that the Civil Judge is passive, which means that the Judge must not decide beyond the charge, based on this principle, a wife who does not demand a living will not get anything. . In civil law they then bear severe consequences, such as not getting protection from the threat of terror or post-trial violence from the ex-husband, not getting the rights to iddah, mut'ah, maskan, kiswah.

Actually a Wife can submit a cumulative claim to get Mut'ah, As has been demonstrated by the Supreme Court which has provided a very good example in the cassation case Number $.276 \mathrm{k} / \mathrm{Ag} / \mathrm{2010}$, namely by granting divorce to the husband who was formulated with demands, mut'ah, hadlonah for children, and children's livelihood, namely by charging mut'ah in the amount of Rp.50,000,000. Consideration of the Supreme Court, because the divorce was filed by the wife caused by the husband remarrying another woman. In fact, the wife's loyalty is more than enough. The attitude of the husband who remarries is an attitude that is not commendable and very painful for a loyal wife.

But usually the Plaintiff (Wife) feels heavy to file a divorce with the provision of mut'ah and hadlonah demands, because it will increase the time long enough to break up the divorce claim. The guagat divorced road with this command is usually not chosen, because it will prolong the unsafe and uncomfortable conditions for the Plaintiff (Wife). In addition to 
\begin{tabular}{l|l} 
Progressivity of Judges in .... & 17
\end{tabular}

the above reasons, the difficulty of being forced to impose penalties to pay for the living of iddah, mut'ah, maskan, kiswah, is if the husband is not present in each trial, so that the Judge is in accordance with the procedural, applying the decision if the divorce claim is granted, then the wife himself must pay a sum of money to pay for the trial and not get for the iddah, mut'ah, maskan, kiswah ${ }^{18}$.

As a consideration based on the positive law that applies, the Religious Court rests on the material of legislation Article 9 of Law Number 23 concerning the Elimination of Domestic Violence and the substance of Article 39 of Act Number 1 of 1974 concerning Jo Marriage. Article 19 Government Regulation Number 09 of 1975 Jo article 116 Compilation of Islamic Law (KHI), a condition of domestic neglect has clearly fulfilled and can be used as a strong reason to file a divorce.

The clearer argumentation as the basis and method of finding the judge's law in the decision consists of: 1. Juridical Documentation (Legislation, Islamic Law and Compilation of Islamic Law (KHI), 2. Yurisprodensi's argument, 3. Customary or Customary Legal Arguments, Ushul Fiqh, Fiqh and the rules of usul fiqh and others), 4. Moral Arguments, 5. Sociological Argument (this argument number 4 and number 5 can be said to be science), 6. Arguments for interpretation or interpretation of law.

Actually, in Book II of the Technical Guidelines of the Religious Courts, it was determined that if the lawsuit was divorced for reasons of husbands' cruelty or violence, the Judge ex-officio could establish a living iddah, in the divorce process, both divorce and claim divorce procedures, as long as the wife did not do nusyuz, still have rights: livelihood of madliyah,

18 Purwosusilo, “Hak-Hak Istri Dalam Perceraian”, disampaikan dalam Seminar: Pemenuhan Hak-Hak Istri Dalam Perceraian, Rifka Anissa Yogyakarta: 8 Desember 2010. http://rifka-annisa.or.id/go/hak-hak-istri-dalamproses-perceraian/ downloaded February 21, 2017, 6-8.

Vol. 2, No. 1, Oktober 2018, 1-29 
18| Nita Triana

mut'ah, livelihood, maskan, kiswah during the iddah period, the right of hadlonah and children's livelihood. Furthermore, the stipulation of these rights can be carried out through divorce claims, recapitalization claims in divorce requests or by an exofficio judge, as in a cassation decision. From the regulation that has been carried out by the Purbalingga Religious Court is in the case of divorce requests for divorce and reconciliation claims in the application for divorce.

In the case of divorce reasons for domestic violence, in the divorce process of divorce, the wife in a recapitulation lawsuit can file a provisional claim, namely the request of the wife as a victim of domestic violence to get a companion. Likewise in the divorce lawsuit, the wife as a plaintiff can submit a provision. In this case, the Purbalingga Religious Court and the Cilacap Religious Court have not fully implemented it, because there is no one from the wife who has proposed (need) assistance as a victim of domestic violence in divorce by talak or divorce petition.

While the amount of the husband's obligation is in the form of living madliyah, mut'ah, livelihood, insurance, kiswah during the iddah period, the right of hadlonah and the child's livelihood. This was agreed upon by the Purbalingga Religious Court. But until now there has been no judge who gave a greater amount, with consideration of the existence of domestic violence in the case.

Empathy from the judges is very likely to arise if the judges understand the root of the persoal, which often cannot be seen from the conditions that occurred at that time. The search for a series of events behind someone to come to the Religious Court requires mastery and holistic analytical skills. Various national laws and regulations can also help Judges to strengthen this capability. For example the Elimination of Domestic Violence PKDRT Law which states various forms of violence, understanding of households, the impact of domestic violence

Ulul Albab: Jurnal Studi dan Penelitian Hukum Islam 
that is threatened by criminal penalties, and so forth will strengthen the Judge's consideration in deciding a case that empathizes with the suffering of victims without leaving the principle of equality in processing cases.

The Child Protection Act can also help to explain the conception of children, a series of children's rights, the obligations of parents to children, child care, forms of violence against children who must receive protection, and so forth. Understanding other scientific fields can guide judges to hold fast to the principle of actively providing assistance as referred to in Article 5 paragraph 2 of Law No. 14 years 1970 Act No. 35 of 1999 jo Law No. 4 of 2004, namely "The court helps justice seekers and strives to overcome obstacles and obstacles as hard as possible to achieve a simple, fast and low cost trial".

Understanding the psycho-social context of victims who are wrapped up in the cycle of violence, the cycle of isolation and confined to the wheel of the power relation of the perpetrator, is very useful for the judges in exercising their authority to resolve this family case. In general, women victims of domestic violence come to the Religious Courts to settle the domestic crisis is the final choice after taking various solutions. This is evident in almost all cases in the Religious Courts which have always stated that there has been a peace effort (mediation) for both parties, but failed.

In article 28 (1) Law No. 4/2004, judges are required to understand the legal value and sense of justice that lives in society. In paragraph 2 , the judge is also required to be able to consider the severity of the crime, the judge must pay attention to the good and evil nature of the defendant (or the parties in a civil case). This code of conduct is certainly not intended for the side of one party without reserve but invites the judges to be able to provide empathy and understanding of the things surrounding a case. 
20| Nita Triana

It is this empathy and understanding that can lead judges to also open and use legal sources and other regulations in addition to the prevalence of Marriage Law and the Compilation of Islamic Law (KHI) based on Islamic law. Articles in the Domestic Violence Law and other laws can be used to strengthen the legal analysis of the religious law in examining cases that are within its authority. Of course the use of these articles relating to domestic violence - as the authority of the Religious Courts - does not impose criminal action on the perpetrators, but is used as a legal basis in explaining what happens in the household relating to domestic violence and seeking justice.

The paradigm of the operation of Judges in a country with a pluralistic culture such as Indonesia, it's time to change to a more progressive direction, Judge is no longer limited to the existence of a mouth that sounds the sentence of the law (le judge est uniquenment la bouche qui pronance le most de lois) the judge is also not tools designed to be logical and work mechanically, but whole people who have sensitivity to humanitarian and social concerns ${ }^{19}$. Even if the judge must read the words listed textually in the law book he must also learn and be good at making interpretations that are not literal (connotative), and have a high sense of empathy to be able to catch social norms that contextually support each prescription of the Act.

But then the problem is that if you look explicitly, there will be no special editor found out about the neglect of the household as the reason for divorce in the legislation in force, because the neglect of the household is a criminal domain, so it is worthy of being examined. the urgency is to create a legal certainty especially in divorce cases

${ }^{19}$ Ruth Lewis, Rebecca, Russell, Kate Cavanagh, “Law's Progressive Potential: The Value of Engagement with the Law for Domestic Violence". Social \& Legal Studies, Vol. 10, No. 1, (London, Thousand Oaks, CA and New Delhi: Sage Publications, 2001), 105-130.

Ulul Albab: Jurnal Studi dan Penelitian Hukum Islam 
Abandonment it self as part of the Law on the Elimination of Domestic Violence is a criminal law source area which in practice can be pursued through civil law (if there are civil rights of the parties violated). Based on that there should be a special mechanism to regulate legal remedies that are carried out due to allegations of domestic neglect. Then it is fitting for the Religious Courts Judge to be more progressive regarding the correct mechanism of legal remedies from neglect, in which the process bridges between two different legal domains (criminal and civil) which requires the Judge to examine thoroughly so that inequality is not removed from sense of justice and legal purpose.

If the Judge Progressiveness in a divorce case cannot be carried out because it is bound by the principles of law and procedural law in the Religious Courts, then it is different from the consideration of the Judge in divorce. Legal considerations Judges in divorce have shown that there is protection for women who are subject to divorce by their marriage. the protection right is given by the Judge, without the wife demanding. The wife's right to protect is in the form of an obligation for the husband to give her a living during the Idah, and a form of income for 1 (one) year as an entertainer. This husband's obligation does not apply to the wife who is Nusyuz, leaving her husband. This can be done, because the judge has a law in book. The Act of both the Act No.1 of 1974 and the Compilation of Islamic Law have indeed regulated this

With the use of Law Number 23 of 2004 concerning Elimination of Domestic Violence, it is hoped that Judicial progression can provide legal protection for victims of domestic violence in a case of a divorce. Judges can protect victims of domestic violence not only in Divorce Divorce cases, but also in the case of Divorce. The judge can be out of the box, out of a very positivisistic box, by providing protection to the Plaintiff (Wife) 
$22 \mid$ Nita Triana

to require the husband to give Mut'ah as an entertainer to the wife, even though this is not a case

Justice is not rigid for the general purpose of the implicative sentence formulated in the articles of the Law. Justice is not a routine task to knock the hammer in the court building. Justice also doesn't need a lazy and blunt judge of his humanity. What is needed is justice is the courage to interpret the Law to elevate Indonesia's human dignity. Issues that occur in Indonesia, the completion of legal problems refers to the principle of work that is measured on the nominal values achieved $^{20}$.

In the State of law a determinant is in the hammer of the judge's trial which is imposed on the final decision ${ }^{21}$. In this case, it is necessary to create judges who are very brave in enforcing the actual legal justice in the sense of not only deciding a case by looking at the facts in the trial alone. In this case the legal community needs to seek justice by affirming the judges as an arm of God.

It is also an urgent matter in the progressive law, namely how to demand the courage of a judge in interpreting the article to civilize this nation towards a better direction. If the process is correct, the ideality built in law enforcement in Indonesia is parallel to the nation's efforts to achieve common goals. This ideal will keep away from the practice of unmanageable legal inequality as it is today. So that in the future Indonesia will no longer have legal discrimination, for the poor, women etc, because the law does not only serve the rich, men, but all the people in the country of Indonesia especially.

20 Suparman Erman, Asal Usul serta Landasan Pembangunan Ilmu Hukum Indonesia Dalam Menggagas Hukum Progresif Indonesia, (Yogyakarta: Pustaka Pelajar, 2006), 129.

${ }^{21}$ J. Chambliss William and Robert B. Seidman, Law, Power and Order, (USA: Addison-Wesley Publishing Company, 1971).

Ulul Albab: Jurnal Studi dan Penelitian Hukum Islam 
If equality before the law cannot be realized, alignment is absolute and eternal. Humans create law not only for certainty, but also for true happiness and justice ${ }^{22}$. But seeing the reality of the Indonesian State in particular has declared itself as a rule of law which has been stated in the 1945 Constitution of the Republic of Indonesia especially in article 1 paragraph (3) which has; "The State of Indonesia is a State of Law" where the benchmark in the settlement of a problem that occurs in the State of Indonesia must be resolved in written law, so that the judges especially in enforcing the law to seek justice must comply with a law that has been ratified by legislators

The most fundamental question in this discussion is whether the judges dare to incorporate progressive law in pursuing complete justice in a court that adheres to a written legal State system such as Indonesia.

Progressive law enforcement is carrying out the law not only words and black-and-white rules (according to the letter), but according to the spirit and meaning more deeply (to very meaning) of the law or law. Law enforcement is not only intellectual intelligence, but with spiritual intelligence. In other words, law enforcement carried out with determination, empathy, dedication, commitment to the nation's suffering and accompanied by the courage of judges to find ways other than what is normally done in the sense that judges must be able to provide social justice.

So if the idea of a progressive court is associated with the level of appeal. We know, at the level of cassation the court no longer sees and discusses facts (judic facti). What is done is to check whether the law has been properly implemented by the lower courts. Cursory reading, people can conclude, what is needed by the Supreme Court is only reading the text of the law

\footnotetext{
22See, Fakih Mansour, Analisis Gender dan Transformasi Sosial, (Yogyakarta: Pustaka Pelajar, 2003), 58.
} 
$24 \mid$ Nita Triana

and using legal logic. Based on the matters revealed in the previous trial levels, the Supreme Court will examine whether the rules used by judges in the Religious Courts, District Courts and High Courts to make decisions are correct. If so, there will be no entrance for the progressive court itself in order to uphold the law. A progressive court is a process full of compassion that contains empathy, determination, conscience, and so on.

The characteristics of such a court would certainly be well expressed when the court itself examined the facts that occurred, not only using rules and logic. There the judge will be able to witness the case itself. The problem becomes serious when we only see the rules and facts presented without extracting further from several sides, including the urgency in solving the problem. Here the judges rely more on how a written law will be read to be applied to the incident recorded in the document.

We do not know whether at the time of reading the Act the chief judge really (could) be "emptied". Whether the reading of the text by the judge takes place in full value. Not that simple. As long as the judge is a human, the complex or predisposing choices available to him will determine how a text is read and interpreted in the existing rules (written rules that are statutory). Linear and nonlinear cassation ${ }^{23}$. Textual positive mind-set will more or less "spell" a rule. Such legal thinking here is called "linear". Indeed, it is very easy, but shallow.

Here we can be reminded again of the opinion of Paul Scholten, a Dutch legal thinker, who said "the law is in the Act, but it still has to be found." It becomes wrong and shallow if people just "spell" the rules ${ }^{24}$. Another way is to contemplate and

${ }^{23}$ Ester Lianawati, Konflik Dalam Rumah Tangga Keadilan \& Kepedulian Proses Hukum KDRT Prespektif Psikologis Feminis, (Yogyakarta: Paradigma Indonesia, 2009).

${ }^{24}$ Friedman.M.Lawrence, The Legal System: A Social Science Perspective, (New York: Russel Sage Foundation, 1975).

Ulul Albab: Jurnal Studi dan Penelitian Hukum Islam 
\begin{tabular}{l|l} 
Progressivity of Judges in .... & 25
\end{tabular}

look for meaning deeper than a rule. This is according to the idea of Paul Scholten. If the "door of contemplation of meaning" is opened, a new panorama unfolds before the judge. Contemplation will not stop in the subjective dimension, but also socially in the sense of the progressive law itself. Judges not only listen with subjective ears, but also with "social ears".

\section{Conclusion}

At the Purbalingga Religious Court, Divorce petition is high. In this divorce petition, it actually describes hidden cases of domestic violence, physical domestic violence is hidden in reasons of disharmony (persistent quarrels), domestic violence is psychologically clearly explained in the reasons for divorce because husbands are not responsible and economic neglect.

At present the Religious Courts Judge has used Law No.23 of 2004 concerning PKDRT (The Elimination of Domestic Violence) in legal considerations for Divorce petition relating to domestic violence. But the application of civil sanctions has not been carried out, the Plaintiff / Wife does not get compensation in the form of iddah, mut'ah, maskan, kiswah. The judge has not been out of the box, because it is tied to the principle of the Civil Judge is passive. Whereas in the case of Divorce by talak, the Judge is a law in book, providing legal considerations in accordance with the rules contained in the Law, namely Law Number 1 of 1974 concerning Marriage Law and Compilation of Islamic Law (KHI) which is considered sufficient to provide protection to a husband who is divorced without a wife must demand about a living, the husband (the applicant) is required to provide a living idah (during the idah period), and Mut'ah for 1 (one) year as an entertainer because of divorce by husband.

The use of interpretation as the influence of community development basically opens the opportunity for Religious Court judges to progressively find legal findings in the protection of victims of domestic violence. Progressive legal 
26| Nita Triana

discovery is inseparable from the desire of conscience to uphold justice by relying on legal values in society. The paradigm that places the judge as a trumpet or mouth piece of the law is very incorrect. In particular, it is affirmed in Law No.48 of 2009 concerning Judicial Power by emphasizing the duty of judges to uphold law and justice.

\section{References}

\section{Book}

Anonim. Pedoman Perilaku Hakim (Code of Conduct). Jakarta: Mahkamah Agung Republik Indonesia.

Ester, Lianawati. 2009. Konflik Dalam Rumah Tangga Keadilan $\mathcal{E}$ Kepedulian Proses Hukum KDRT Prespektif Psikologis Feminis. Yogyakarta: Paradigma Indonesia.

Faqihuddin, Abdul Kodir dan Ummu Azizah Mukarnawati, Referensi bagi Hakim Peradilan Agama tentang Kekerasan dalam Rumah Tangga. 2013. Jakarta: Komnas Perempuan.

Friedman, M. Lawrence. 1975. The Legal System: A Social Science Perspective. New York: Russel Sage Foundation. dan Antonius Cahyadi. 2008. Runtuhnya Sekat Perdata dan Pidana: Studi Peradilan Kasus Kekerasan terhadap Perempuan. Jakarta: Yayasan Obor Indonesia.

LBH APIK. 2012. Refleksi dan Catatan kerja LBH APIK Jakarta tahun 2011. Jakarta: LBH APIK.

Manan, Abdul dan Fauzan. 2000. Pokok-Pokok Hukum Perdata Wewenang Peradilan Agama. Jakarta: Rajawali Pers.

Mansour, Fakih. 2003. Analisis Gender dan Transformasi Sosial. Yogyakarta: Pustaka Pelajar.

Nonet, Philippe and Philip Selznick. 1978. Law and society in transition: toward responsive law. USA: Harper \& Row.

Rahardjo, Satjipto. 2009. Hukum Progresif-Sebuah Sintesa Hukum Indonesia. Yogyakarta: Genta Publishing.

Ulul Albab: Jurnal Studi dan Penelitian Hukum Islam 
\begin{tabular}{l|l} 
Progressivity of Judges in .... & 27
\end{tabular}

2006. Membedah Hukum Progresif. Jakarta:

PT. Kompas.

. 2009. Sekitar Hakim yang Memutus.

Kumpulan Tulisan Program Doktor Ilmu Hukum Semarang: UNDIP.

. 2009. Ilmu Hukum dan Fisiologi Otak.

Kumpulan Tulisan Program Doktor Ilmu Hukum. Semarang: UNDIP.

. 2008. Biarkan Hukum Mengalir-Catatan

Kritis Tentang Pergulatan Manusia dan Hukum. Jakarta: Penerbit Buku Kompas.

Strauss, A., \& Corbin, J.M. 1990. Qualitative Research, Grounded Theory Procedure and Techniques. Thousand Oaks, CA, US: Sage Publication.

Suparman, Erman. 2006. Asal Usul serta Landasan Pembangunan Ilmu Hukum Indonesia Dalam Menggagas Hukum Progresif Indonesia. Ahmad Gunawan dan Muamar Ramadhan (Penyunting). Yogyakarta: Pustaka Pelajar.

Tamanaha Z Brian. 2004. On the Rule of Law. New York: Cambridge University Press.

William, J. Chambliss and Robert B. Seidman. 1971. Law, Power Journals

and Order. USA: Addison-Wesley Publishing Company.

Aisyah S., Parker L. Problematic Conjugations: Women's Agency, Marriage, and Domestic Violence in Indonesia. Asian Studies Review Journal, Volume 382014.

Chomsky Carol, Progressive Judges in a Progressive Age: Regulatory Legislation in the Minnesota Supreme Court, 1880-1925, Journal Law and History Review. Vol.11,No.2,Autumn,1993 Published by: American Society for Legal History US 2001 
28| Nita Triana

Hoecke Mark Van, Methodologies Of Legal Research (Which Kind of Method For What Kind of Dicipline), Europian Academy of Legal Theory .Vol:9. Oxford and Portland, Oregon-2011

Irianto Sulistyowati dan Lim Sing Meij. Praktek Penegakan Hukum: Arena Penelitian Sosiolegal yang Kaya. Metode Penelitian Hukum -Konstelasi dan Refleksi. Jurnal JHMP -(Terakreditasi) FH UI. Yayasan Obor Jakarta.2009.

Lewis, Ruth, Rebecca, Russell, \& Kate Cavanagh. 2001. Law's Progressive Potential: The Value of Engagement With The Law For Domestic Violence. London, Thousand Oaks, CA and New Delhi: SAGE Publications. Vol. 10, No. 1:105-130.

Rodiyah. 2017. Philosophy of Progressive Law On Establishment of Laws and Regulation in The Context of Substantive justice: An Indonesian Experience. Journal of Business, Economics and Law. Vol. 13, Issue 4.

Syamsudin, M. 2011. Rekonstruksi Pola Pikir Hakim Dalam Memutus Perkara Korupsi Berbasis Hukum Progresif. Purwokerto: Jurnal Dinamika Hukum.Vol. 11, No.1.

Triana, Nita. 2011. Progresifitas Hakim dalam Dinamika Positivisasi Hukum Islam di Indonesia. Purwokerto: Al Manahij: Jurnal Kajian Hukum Islam. Vol.5, No. 2.

Tulab, Tali. 2017. Tinjauan Status Wali Dalam Perkawinan Berdasar Pendekatan Feminis. Semarang: Ulul Albab: Jurnal Penelitian dan Studi Hukum Islam. Vol. 1, No. 1.: 162.

\section{Internet}

Purwosusilo. 2017. Hak-Hak Istri Dalam Perceraian. Disampaikan dalam Seminar : Pemenuhan Hak-Hak Istri Dalam Perceraian. Rifka Anissa Yogyakarta: 8 Desember 2010. http://rifka-annisa.or.id/go/hak-hak-istri-dalamproses-perceraian/ downloaded February 21, 2017.

Ulul Albab: Jurnal Studi dan Penelitian Hukum Islam 
\begin{tabular}{l|l} 
Progressivity of Judges in .... & 29
\end{tabular}

https://www.komnasperempuan.go.id/reads-catatan-tahunankekerasan-terhadap-perempuan-2017

Law

Konstitusi UUD 1945 (constitution of 1945)

Undang-Undang Nomor.1 Tahun 1974 tentang Perkawinan (Law Number. 1 of 1974 concerning marriage)

Instruksi Presiden Nomor 1 Tahun 1991 tentang Kompilasi Hukum Islam (Presidential Instruction Number 1 of 1991 concerning Compilation of Islamic Law)

Undang-Undang Nomor .7 Tahun 1984 tentang Pengesahan Konvensi Mengenai Penghapusan Segala Bentuk Diskriminasi Terhadap Wanita (Law Number 7 of 1984 concerning Ratification of the Convention Regarding the Elimination of All Forms of Discrimination Against Women)

Undang-Undang Nomor. 23 Tahun 2002 tentang Perlindungan Anak,( Law Number. 23 of 2002 concerning Child Protection)

Undang-Undang Nomor . 23 Tahun 2004 tentang Penghapusan Kekerasan Dalam Rumah Tangga (Law Number. 23 of 2004 concerning Elimination of Domestic Violence) 